\title{
EFFECT OF ENRICHING MULBERRY LEAVES WITH CERTAIN FOLIAR FERTILIZERS ON SOME PHYSIOLOGICAL ASPECTS OF MULBERRY SILKWORM, Bombyx mori L.
}

\author{
A. A. Zannoon; Eman, M. Hassan and Ghada, A. Morsy \\ Plant Prot. Research Institute, A.R.C., Egypt.
}

\section{ABSTRACT}

Studies were conducted to evaluate the effect of certain foliar fertilizers (Basfoliar combi ctip, Tecamin max and Stimoful) as a nutritional additives on some physiological aspects in haemolymph of mulberry silkworm, Bombyx mori L. Mulberry leaves were dipped in three concentrations for each tested foliar fertilizer (1, 2 and 3\%) and offered to the first group larvae at the beginning of the $4^{\text {th }}$ larval instar. The second group was treated at the beginning of both $4^{\text {th }}$ and $5^{\text {th }}$ instar larvae.

Results showed that total protein increased as concentration increased in the two groups. Tecamin max gave the highest mean of total protein in two groups. Stimoful gave the highest mean of total carbohydrate in the two groups. The concentration 3\% from stimoful recorded the highest content from total carbohydrate in both groups. Tecamin max gave the highest mean of Glutamic oxaloacetic transaminase (GOT) and glutamic pyruvic transaminase (GPT) enzyme activities in both groups. Larvae fed on leaves treated by Basfoliar combi ctip gave the highest activity of amylase enzyme in both groups and the concentration 3\% recorded the highest level of amylase activity. Tecamin max gave the highest level of invertase activity on the first group, while stimoful recorded the highest mean of invertase activity on the second group. The highest level of Trehalase activity was $83.53 \mathrm{mg}$ glucosel $\mathrm{ml}$ for stimoful on the first group, while Basfoliar combi ctip recorded the highest level of trehalase activity on the second group.

Conclusively, fortification of mulberry leaves with different nutritional additives as foliar fertilizers increased some physiological aspects of mulberry silkworm B. mori especially as concentration increased.

Keywords: Enriching mulberry leaves, foliar fertilizers, physiological aspects, Bombyx mori L. 


\section{INTRODUCTION}

The mulberry silkworm, Bombyx mori L., (Bombycidae, Lepidoptera) is one of the most economically important insects not only on the national level but also internationally. The importance of this insect developed from its ability of secreting the natural silk filament from its silk gland, so a considerable attention has been given recently to improve rearing of this insect and to increase the production of raw natural silk, which considered as one of the most important fibers in local and world markets. The production of high quality and quantity of natural silk depends mainly on larval feeding. Therefore, it has been reported recently that better production of cocoon crops and eggs is possible when mulberry leaves are supplemented with certain nutritional materials, the mulberry silkworms, Bombyx mori require calcium, iron, magnesium, manganese, phosphorus, potassium and zinc for their growth and development (Ito 1978; Parra, 1991; Mahesha et al., 1999 and Mesbah et al., 2000).

Mulberry leaves are rich in protein and amino acids. Nearly $70 \%$ of silk proteins produced by the silkworm are directly derived from proteins of mulberry leaves, therefore an increase in protein level of mulberry leaves may lead to improvements in silk productivity (Machii, 1989). Murugan et al. (1998) demonstrated that the dietary nutritional management has a direct influence on quality and quantity of silk production in B. mori.

Singhal and Rajan (1998) found that the nutritive value of mulberry (Morus spp.) leaves greatly influences the growth and development of silkworm B. mori and is the primary factor responsible for a successful cocoon crop, in turn increasing silk yield. Larval growth was largely depended on the dietary protein supplemented with fertilizer element or vitamins. Nutritive protein plays an important role on protein synthesis with decrease or increase in haemolymph of silkworm larvae with reflect to body weight, silk gland and silk proteins, this figure is obtained by those of Das et al.(2004), Bhattachanya and Kaliwal (2005), Ashfag et al. (2006) and Wagiha and Mona (2008).

Carbohydrates are of vital importance since they can be utilized by the insects' body for production of energy or conversion to lipids or proteins. Metabolism of carbohydrates is controlled mainly by carbohydrate hydrolyzing enzymes which play a principal role in digestion and utilization of carbohydrate by insect. It is controlled mainly by amylase, invertase and trehalase enzymes. Trehalose is one of the most important storage carbohydrates that is present in almost all forms of life except mammals. Trehalose splits into glucose units by trehalase enzyme. Amylase enzyme is required to digest carbohydrates (polysaccharides) into smaller units (disaccharides), and eventually into even smaller units (monosaccharides) such as glucose. Invertase enzyme is believed to be important for digestion 
and utilization of sucrose by insects; hydrolyzes sucrose, forming fructose and glucose. The final product of carbohydrates metabolism is glucose, the increase of these enzymes during the larval stage suggested that these enzymes degrade carbohydrates to glucose for chitin build-up (Franco et al., 2000; Franco et al., 2002 and Naveed et al., 2009).

El-Sheakh et al. (1994) reported that a clear differences was found between larval fed on fresh and stored leaves concerning GPT and GOT and enzymes activity.

Therefore, the present investigation was to study; the effects of three foliar fertilizers (Basfoliar combi ctip, Tecamin max and Stimoful) as nutritional additives on some physiological aspects such as; total protein, total carbohydrates, GOT and GPT enzymes and amylase, invertase and trehalase hydrolyzing enzymes.

\section{MATERIALS AND METHODS}

The present study was carried out during the spring season of 2010 in the laboratory of Sericulture Research Department of Plant Protection Research Institute, Sharkia Branch, Agriculture Research Center. It aims to investigate the effects of some foliar fertilizers as nutritional additives on some physiological aspects of silkworm Bombyx mori.

\section{I- Materials:}

1. Mulberry leaves variety used: Morus alba variety (Japanese).

2. Mulberry silkworm, B. mori eggs (Egyptian hybrid Giza).

\section{Foliar fertilizers:}

\section{a- Basfoliar combi ctipb.:}

Contents: $\mathrm{Br} 0.2 \%$ - Mn $4 \%-\mathrm{N} 9 \%$ - Ca $15 \%$ - Mg $1 \%$ used as solution product by compo. Germany shoura chemicals Egypt.

\section{b-Tecamin Max.}

Contents: L. amino acids $12 \%$ - Total amino acid $14.4 \%-\mathrm{N} 7 \%$ used as solution product by Marchal Marten. Aspin.

\section{c-Stimufol.}

Contents: N $25 \%-$ P $16 \%-$ K $12 \%$ used as solution product by Marchal Marten. Aspin.

- Each of the tested compounds was used at three concentrations 1,2 and $3 \%$ add to tap water.

\section{Methods:}

\section{- Rearing technique.}

Rearing was carried out on fresh mulberry leaves (Japanese variety) under laboratory conditions of $26 \pm 3{ }^{\circ} \mathrm{C}$ and $70 \pm 5 \% \mathrm{RH}$, according to the technique of Krishnaswami (1978). 
Mulberry leaves were dipped in the three prepared concentrations for each used foliar fertilizer for one minute and left to dry and offered to two groups of silkworm larvae; the first group larvae were fed with treated leaves only one time at the beginning of $4^{\text {th }}$ larval instar and the second group were fed two times at the beginning of $4^{\text {th }}$ and $5^{\text {th }}$ larval instars. The control leaves were dipped in distilled water.

\section{Physiological measurements:}

- Preparation of samples for biochemical assay:-

Samples were made by removing one of the thoracic legs of the $5^{\text {th }}$ instar larvae and bending the body to expose the sternum at the position of the removed leg. This ensured proper drainage of the heamolymph, and avoided any risk of internal organs to be destructed. The haemolymph of each treatment was collected in eppendorf tubes $1.5 \mathrm{ml}$ with small crystal of phenyl thiourea (PTU) to prevent melanization of sample, (Mahmoud, 1988). The tubes were kept at $-20^{\circ} \mathrm{C}$. The blood samples were centrifuged at 10000 r.p.m for 10 minutes at $5^{\circ} \mathrm{c}$. The supernatant was immediately assayed to determine total soluble protein, total carbohydrate and activities of glutamic oxaloacetic transaminase (GOT), glutamic pyruvic transaminase (GPT), trehalase, amylase and invertase enzymes as follows:

\section{Determination of total protein:-}

Colorimetric determination of total soluble protein in supernatant of haemolymph of B. mori was carried out as described by Gornall et al. (1949). A volume of $0.4 \mathrm{ml}$ of haemolymph sample was added to $5 \mathrm{ml}$ of biuret reagent and incubated for $30 \mathrm{~min}$. at $20-25^{\circ} \mathrm{C}$. The absorbency of the sample against a blank biuret reagent was measured at wavelength of 546 $\mathrm{nm}$ using UV visible spectrophotometer. The total protein content of haemolymph samples was estimated as $\mathrm{mg} / \mathrm{ml}$ using the following formula derived from the equation of the straight line (Intercept $=0.0147$, Slop $=$ 0.003, ABS $=$ Absorbance).

$$
\begin{aligned}
\text { Protein content } & =\frac{\text { ABS }-0.0147}{\text { O.0O3 }} \\
\text { Protein content } & =\frac{\text { Absorbance }- \text { Interecption }}{\text { slop }}=\mathrm{mg} / \mathrm{ml}
\end{aligned}
$$

\section{Determination of total carbohydrate:-}

All carbohydrate fractions were determined according to Ishaaya and Swiriski (1976).

The total carbohydrate content of haemolymph samples was estimated as $\mathrm{mg} / \mathrm{ml}$ using the following formula derived from the equation of the straight line. Intercept $=0.0073$, slop $=0.0138$.

$$
\text { Carbohydrate content }=\frac{\text { ABS }-0.0073}{0.0138} \text { ) }
$$


Carbohydrate content $=\frac{\text { Absorbance }- \text { Interception }}{\text { slop }}=\mathrm{mg} / \mathrm{ml}$

\section{Determination of enzymes activities:}

\section{Transaminase enzymes (GOT \& GPT):-}

Glutamic oxaloacetic transaminase (GOT) and glutamic pyruvic transaminase (GPT) enzyme activities were determined colorimetrielly according to the method of Reitman and Frankel (1957).

The reaction mixture consisted of $1 \mathrm{ml}$ of a mixture of phosphate buffer (PH 7.4), $0.2 \mathrm{mM}$. $\alpha$-ketoglutaric and $200 \mathrm{mM}$. D-L-alanine or Laspartate and $0.2 \mathrm{ml}$ of heamolymph supernatant were then added to the reaction mixture. The mixture was incubated on water bath at $40{ }^{\circ} \mathrm{C}$ for 30 min. then $10 \mathrm{ml}$ of $0.4 \mathrm{~N}$. NaOH was added. The optical density of the produced brown color is measured after $5 \mathrm{~min}$. using spectrophotometer at $520 \mathrm{~nm}$.

The glutamic oxaloacetic transaminase (GOT) and glutamic pyruvic transaminase (GPT) enzyme activities was estimated as $\mathrm{mg} / \mathrm{ml}$ using the following formula derived from the equation of the straight line.

$$
\begin{aligned}
& \text { GPT or GOT content }=\frac{\text { Absorbance }- \text { Interception }}{\text { slop }}=\mathrm{mg} / \mathrm{ml} \\
& \text { Intercept }=0.0053, \text { slop }=0.0164\left(\text { GPT content }=\frac{\mathrm{ABS}-0.0053}{0.0164}\right) \\
& \text { Intercept }=0.023, \text { slop }=0.0019\left(\text { GOT content }=\frac{\text { ABS }-0.023}{0.0019}\right)
\end{aligned}
$$

\section{Determining the activities of the carbohydrate hydrolyzing enzymes} (amylase, invertase and trehalase) in supernatants of haemolymph:-

Amylase, invertase and trehalase activities in supernatants of haemolymph were determined following the method described by Ishaaya and Swiriski (1976).

The amylase reaction mixture consisted of $0.2 \mathrm{ml}$ of $2 \%$ starch (substrate), $0.160 \mathrm{ml}$ phosphate buffer and $0.5 \mathrm{ml}$ haemolymph supernatant.

The invertase reaction mixture consisted of $0.2 \mathrm{ml}$ of $3 \%$ trehalose (substrate), $0.2 \mathrm{ml}$ phosphate buffer $\mathrm{PH} 5.4$ ) and $0.5 \mathrm{ml}$ of haemolymph supernatant.

The trehalase reaction mixture consisted of $0.2 \mathrm{ml}$ of $2 \%$ starch (substrate), $0.160 \mathrm{ml}$ phosphate buffer and $0.5 \mathrm{ml}$ haemolymph supernatant.

The dinitrosalic acid reagent was prepared by dissolving one gram of 3.5 - dinitrosa licylic acid in $20 \mathrm{ml}$ of $2 \mathrm{~N} \mathrm{NaoH}$ and $50 \mathrm{ml}$ of distilled water with the aid of a magnetic stirrer. Potassium sodium tartarate (30 gm.) was added, and magnetic stirring was continued until a clear solution was obtained. Distilled water was then added to bring the final volume to 
$100 \mathrm{ml}$. All tests were incubated at $37^{\circ} \mathrm{C}$ for exactly 60 minutes, $0.8 \mathrm{ml}$ of 3.5 dintro salicylic acid reagent were then added. The reaction mixture wash heated for 5 minutes at $100^{\circ} \mathrm{C}$ in a boiling water bath followed by immediate cooling in an ice bath. The optical density (OD) of the produced colour is measured at $550 \mathrm{~nm}$ using spectrophotometer. The enzymatic activity was expressed as $\mu \mathrm{g}$ glucose released/1mg. haemolymph supernatant weight / minutes.

\section{Statistical analysis:-}

The obtained results were subjected to statistical analysis of variance and the data were presented as means according to Snedecor and Cochran (1982) methods using software COSTAT program.

\section{RESULTS AND DISCUSSION}

Data regarding the biochemical analysis of total protein, total carbohydrate, protein enzymes (GOT and GPT) and carbohydrate hydrolyzing enzymes (Amylase, Invertase and Trehalase) in the haemolymph of silkworm larvae fed on used foliar fertilizers and their concentrations as systemic schedules. The detailed results are as follow:

\section{Total protein:}

Data in Table (1) showed that the silkworm larvae fed on mulberry leaves supplemented with Tecamin max at the beginning of the $4^{\text {th }}$ instar larvae recorded the highest mean of total protein in their haemolymph $(102.28 \mathrm{mg} / \mathrm{ml})$ followed by Stimoful $(85.79 \mathrm{mg} / \mathrm{ml})$ and Basfoliar $(79.34$ $\mathrm{mg} / \mathrm{ml}$ ). The concentration 3\% from Tecamin max gave the highest total protein $(113.05 \mathrm{mg} / \mathrm{ml})$ compared with other concentrations and control. Highly significant differences were found between the compound and control.

Larvae fed on investigated compounds two times at the beginning of the $4^{\text {th }}$ and $5^{\text {th }}$ instars represented in Table (2) showed the same results as the first group; Tecamin max exhibited the highest mean of total protein $(117.13 \mathrm{mg} / \mathrm{ml})$ compared with Basfoliar and Stimoful. The concentration $3 \%$ from Tecamin max gave the highest total protein $(124.06 \mathrm{mg} / \mathrm{ml})$ compared with other concentrations. Highly significant differences were found between treatment and control.

These results explained by Nagata and Kobayashi (1990), cleared that, the nutritional richness in the diet influenced the accumulation of storage proteins in the haemolymph of the silkworm larvae i.e. the quantity of storage protein in the silkworm larvae fed on low protein were less than the standard diet but the larvae fed on optimal level of protein show a higher 
Table 1: Effect of adding certain foliar fertilizers one time at the beginning of the $4^{\text {th }}$ instar larvae of $B$. mori on total proteins, total carbohydrates and enzymes activities; GOT \& GPT (mg/ml) of haemolymph.

\begin{tabular}{|c|c|c|c|c|c|}
\hline Compounds & Concentration & $\begin{array}{c}\text { Total } \\
\text { protein }\end{array}$ & $\begin{array}{c}\text { Total } \\
\text { carbohydrates }\end{array}$ & GOT & GPT \\
\hline \multirow{4}{*}{$\begin{array}{l}\text { Basfoliar } \\
\text { combi ctip }\end{array}$} & $1 \%$ & 66.25 & 1.01 & 39.56 & 21.06 \\
\hline & $2 \%$ & 79.23 & 1.27 & 44.18 & 24.55 \\
\hline & $3 \%$ & 92.55 & 2.06 & 50.16 & 26.19 \\
\hline & Means & 79.34 & 1.45 & 44.63 & 23.93 \\
\hline \multirow{4}{*}{ Tecamin max } & $1 \%$ & 94.79 & 2.14 & 46.52 & 31.4 \\
\hline & $2 \%$ & 99.00 & 1.00 & 59.06 & 23.23 \\
\hline & $3 \%$ & 113.05 & 0.82 & 62.29 & 18.19 \\
\hline & Means & 102.28 & 1.32 & 55.96 & 24.27 \\
\hline \multirow{4}{*}{ Stimoful } & $1 \%$ & 60.14 & 1.72 & 37.89 & 19.31 \\
\hline & $2 \%$ & 89.17 & 2.34 & 67.08 & 25.24 \\
\hline & $3 \%$ & 108.07 & 2.88 & 51.11 & 27.10 \\
\hline & Means & 85.79 & 2.31 & 52.03 & 23.88 \\
\hline \multicolumn{2}{|c|}{ Control } & 77.00 & 1.01 & 42.16 & 20.18 \\
\hline \multicolumn{2}{|c|}{ L.S.D 0.05 Compounds } & $6.432 * * *$ & $0.273 * * *$ & $6.398 * * *$ & n.s \\
\hline \multicolumn{2}{|c|}{ L.S.D 0.05 Concentrations } & $5.571 * * *$ & n.s & $\mathbf{5 . 5 4 1 * * *}$ & n.s \\
\hline
\end{tabular}

levels of storage protein. In addition, Mullins (1985) reported that the haemolymph proteins content of the lepidopterous larvae ranged from 60 to $100 \mathrm{mg} / \mathrm{ml}$. Moreover, these results are in agreement with Sarker et al. (1995) who cleared that growth of larvae of B. mori significantly affected by fed on mulberry leaves supplemented with different nutrients, the total protein of silk gland increased.

Das et al. (2004) revealed that detection of the highest level of soluble protein after fourth molt and simultaneous gradual increase in the free amino acids in the silk gland up to the end of larval stage reflected the possibility of active function of the protein synthesis mechanism in the silk gland.

\section{Total carbohydrates:}

Stimoful compound exhibited significantly increased in the mean of total carbohydrates $(2.31 \mathrm{mg} / \mathrm{ml})$ as shown in Table (1) compared to control group $(1.01 \mathrm{mg} / \mathrm{ml})$ followed by Basfoliar combi ctip $(1.45 \mathrm{mg} / \mathrm{ml})$ and Tecamin max compound $(1.32 \mathrm{mg} / \mathrm{ml})$. 
As illustrated in Table (2) stimoful compound exhibited significantly the highest value in total carbohydrates of larvae fed two times at the beginning of the $4^{\text {th }}$ and $5^{\text {th }}$ larval instars $(2.41 \mathrm{mg} / \mathrm{ml})$ followed by Basfoliar combi ctip $(1.52 \mathrm{mg} / \mathrm{ml})$ and Tecamin max compound $(1.46$ $\mathrm{mg} / \mathrm{ml}$ ). The concentration (3\%) from stimoful recorded the highest value $(2.80 \mathrm{mg} / \mathrm{ml})$ compared with the concentrations of the other compounds and control.

Singaravelu et al. (2004) reported that oral supplementation of magnesium sulphate with different concentrations of silkworm larvae resulted in significant influence on biochemical parameters (protein, carbohydrates and lipid) of digestive tissues.

These results are disagree Sarker et al. (1995) who reported that larvae of $B$. mori fed on mulberry leaves supplemented with different nutrients exhibited carbohydrates content decreased and this may be due to the different constituents of the treated materials.

\section{3- Glutamic oxaloacetic transaminase (GOT):}

The concentration $3 \%$ of Tecamin max compound $(62.29 \mathrm{mg} / \mathrm{ml})$ and the concentration $2 \%$ of Stimoful $(67.08 \mathrm{mg} / \mathrm{ml})$ gave significantly the highest values of GOT compared with the other concentrations. Fed the $4^{\text {th }}$ instar larvae on leaves treated with Tecamin max gave the highest value of GOT $(55.96 \mathrm{mg} / \mathrm{ml})$ compared with the other compounds and control $(42.16 \mathrm{mg} / \mathrm{ml})$ as shown in Table 1.

Data presented in Table (2) showed that means of GOT enzyme of haemolymph of silkworm larvae fed on the three compounds two times at the beginning of the $4^{\text {th }}$ and $5^{\text {th }}$ instars revealed that Tecamin max compound gave $(60.88 \mathrm{mg} / \mathrm{ml})$ and stimoful $(58.24 \mathrm{mg} / \mathrm{ml})$ followed by Basfoliar combi ctip $(48.21 \mathrm{mg} / \mathrm{ml})$ compared with control. The concentration $2 \%$ of stimoful gave the highest value of GOT activity $(72.33 \mathrm{mg} / \mathrm{ml})$ compared with the other concentrations.

\section{4- Glutamic pyruvic transaminase (GPT):}

Statistical analysis of data revealed that no significant differences $(P>0.05)$ between the means of GPT activity for the three additive compounds. No significant differences were found between concentrations (Table 1).

As shown in Table (2), GPT activity was increased as concentration increased, except Tecamin max GPT activity was decreased. Tecamin $\max (27.23 \mathrm{mg} / \mathrm{ml})$ and Stimoful $(26.84 \mathrm{mg} / \mathrm{ml})$ gave the highest GPT activity compared to control $(20.18 \mathrm{mg} / \mathrm{ml})$.

The present discussion in convenient with $\mathrm{Li}$ and Zhu (1985) studied the results indicated that amino transfers was involved in the uptake of nitrogen from the leaves by the body tissues and silk gland, which resulted in 
Table 2: Effect of adding certain foliar fertilizers two times at the beginning of the $4^{\text {th }}$ and $5^{\text {th }}$ instar larvae of $B$. mori on total proteins, total carbohydrates and enzymes activities; GOT \& GPT $(\mathrm{mg} / \mathrm{ml})$ of haemolymph.

\begin{tabular}{|c|c|c|c|c|c|}
\hline Compounds & Concentration & $\begin{array}{c}\text { Total } \\
\text { protein }\end{array}$ & $\begin{array}{c}\text { Total } \\
\text { carbohydrates }\end{array}$ & GOT & GPT \\
\hline \multirow{4}{*}{$\begin{array}{l}\text { Basfoliar } \\
\text { combi ctip }\end{array}$} & $1 \%$ & 78.07 & 1.02 & 43.09 & 22.15 \\
\hline & $2 \%$ & 90.10 & 1.31 & 48.41 & 26.09 \\
\hline & $3 \%$ & 111.16 & 2.24 & 53.12 & 27.11 \\
\hline & Means & 93.11 & 1.52 & 48.21 & 25.12 \\
\hline \multirow{4}{*}{ Tecamin max } & $1 \%$ & 109.35 & 2.25 & 51.12 & 34.35 \\
\hline & $2 \%$ & 117.98 & 1.15 & 65.18 & 27.10 \\
\hline & $3 \%$ & 124.06 & 0.98 & 66.34 & 20.23 \\
\hline & Means & 117.13 & 1.46 & 60.88 & 27.23 \\
\hline \multirow{4}{*}{ Stimoful } & $1 \%$ & 67.80 & 1.97 & 47.10 & 22.15 \\
\hline & $2 \%$ & 100.37 & 2.46 & 72.33 & 28.62 \\
\hline & $3 \%$ & 110.44 & 2.80 & 55.30 & 29.76 \\
\hline & Means & 92.87 & 2.41 & 58.24 & 26.84 \\
\hline \multicolumn{2}{|l|}{ Control } & 77.00 & 1.01 & 42.16 & 20.18 \\
\hline L.S.D 0.05 & Compounds & $6.04 * * *$ & $0.243 * * *$ & $5.351 * * *$ & $5.351 *$ \\
\hline \multicolumn{2}{|c|}{ L.S.D 0.05 Concentrations } & $5.231 * * *$ & 0.211* & $4.634 * * *$ & n.S \\
\hline
\end{tabular}

the subsequent promotion of silk protein synthesis. Similar results were obtained by Singh et al. (1985) found that enzyme activities of (GOT) was higher than (GPT) in haemolymph of silkworm larvae fed on mulberry leaves treated with used treatments.

\section{5- Amylase:}

Data presented in Table (3) showed that the mean amylase activities were $65.12,39.47$ and $53.39 \mathrm{mg}$ glucose/ml for Basfoliar combi ctip, Tecamin max and stimoful respectively compared with $42.73 \mathrm{mg}$ glucose $/ \mathrm{ml}$ for control. Statistical analysis showed highly significantly between mean of the three fertilizers and control when $4^{\text {th }}$ instar larvae fed on the treated mulberry leaves. When the larvae fed two times at the beginning of the $4^{\text {th }}$ and $5^{\text {th }}$ instar (Table 4), the activities of amylase were 81.91, 37.32 and $61.51 \mathrm{mg}$ 
Table 3: Effect of adding certain foliar fertilizers one time at the beginning of the $4^{\text {th }}$ instar larvae of $B$. mori on activities of carbohydrate hydrolyzing enzymes ( $\mathrm{mg}$ glucose/ $\mathrm{ml}$ ) of haemolymph.

\begin{tabular}{|c|c|c|c|c|}
\hline Compounds & Concentration & Amylase & Invertase & Trehalase \\
\hline \multirow{4}{*}{$\begin{array}{c}\text { Basfoliar } \\
\text { combi ctip }\end{array}$} & $\mathbf{1 \%}$ & 51.66 & 47.91 & 66.15 \\
\cline { 2 - 5 } & $\mathbf{2 \%}$ & 63.02 & 84.44 & 85.65 \\
\cline { 2 - 5 } & $\mathbf{3 \%}$ & 80.68 & 67.38 & 76.16 \\
\cline { 2 - 5 } & Means & $\mathbf{6 5 . 1 2}$ & $\mathbf{6 6 . 5 8}$ & $\mathbf{7 5 . 9 9}$ \\
\cline { 2 - 5 } Tecamin \\
max & $\mathbf{1 \%}$ & 40.11 & 112.45 & 69.07 \\
\cline { 2 - 5 } & $\mathbf{2 \%}$ & 53.12 & 87.17 & 53.23 \\
\hline \multirow{4}{*}{ Stimoful } & $\mathbf{3 \%}$ & 25.17 & 52.19 & 48.68 \\
\cline { 2 - 5 } & $\mathbf{1 \%}$ & $\mathbf{3 9 . 4 7}$ & $\mathbf{8 3 . 9 4}$ & $\mathbf{5 6 . 9 9}$ \\
\cline { 2 - 5 } & $\mathbf{2 \%}$ & 51.65 & 71.32 & 60.19 \\
\cline { 2 - 5 } & $\mathbf{3 \%}$ & 67.18 & 76.15 & 68.47 \\
\hline Means & $\mathbf{5 3 . 3 9}$ & $\mathbf{8 2 . 9 7}$ & $\mathbf{6 9 . 6 4}$ \\
\hline Control & $\mathbf{4 2 . 7 3}$ & $\mathbf{5 7 . 1 3}$ & $\mathbf{5 3 . 3 5}$ \\
\hline L.S.D 0.05 Compounds & $\mathbf{5 . 3 5 1} * * *$ & $\mathbf{5 . 3 5 1} * * *$ & $\mathbf{5 . 3 5 1} * * *$ \\
\hline L.S.D 0.05 Concentrations & $\mathbf{4 . 6 3 4} * * *$ & $\mathbf{4 . 6 3 4} *$ & n.s \\
\hline
\end{tabular}

glucose/ml for the three fertilizers respectively. The concentration $3 \%$ of Basfoliar combi ctip recorded the highest activity of amylase compared with other concentrations.

\section{6- Invertase :}

As shown in Table (3), cleared that Tecamin max compound recorded the highest mean of invertase activity compared with Basfoliar and Stimoful compound. Highly significant differences were found between the three treatments and control when the $4^{\text {th }}$ instar larvae fed on mulberry leaves treated with the three fertilizers. While, when fed two times at $4^{\text {th }}$ and $5^{\text {th }}$ instars larvae the mean of invertase activities were 82.87, 88.58 and $91.18 \mathrm{mg}$ glucose/ml for the three fertilizers respectively. Statistical analysis showed highly significantly between the mean of the three fertilizers and control (Table 4).

\section{7- Trehalase:}

As shown in Table (3), cleared that the $4^{\text {th }}$ instar larvae fed on mulberry leaves treated with different fertilizers were affected significantly on the mean of trehalase enzyme. The means of trehalase were 75.99, 56.99 and $69.64 \mathrm{mg}$ glucose/ml for Basfoliar combi ctip, Tecamin max and stimoful, respectively 
Table 4: Effect of adding certain foliar fertilizers two times at the beginning of the $4^{\text {th }}$ and $5^{\text {th }}$ instar larvae of $B$. mori on activities of carbohydrate hydrolyzing enzymes ( $\mathrm{mg}$ glucose/ $\mathrm{ml}$ ) of haemolymph.

\begin{tabular}{|c|c|c|c|c|}
\hline Compounds & Concentration & Amylase & Invertase & Trehalase \\
\hline \multirow{4}{*}{ Basfoliar combi ctip } & $\mathbf{1 \%}$ & 73.65 & 58.18 & 70.27 \\
\cline { 2 - 5 } & $\mathbf{2 \%}$ & 79.90 & 110.43 & 96.09 \\
\cline { 2 - 5 } & $\mathbf{3 \%}$ & 92.17 & 80.00 & 84.24 \\
\cline { 2 - 5 } & Means & 81.91 & 82.87 & 83.53 \\
\cline { 2 - 5 } & $\mathbf{1 \%}$ & 38.11 & 120.06 & 77.10 \\
\cline { 2 - 5 } & $\mathbf{2 \%}$ & 47.56 & 100.61 & 62.45 \\
\cline { 2 - 5 } Tecamin max & $\mathbf{3 \%}$ & 26.30 & 45.09 & 33.39 \\
\hline \multirow{3}{*}{ Stimoful } & $\mathbf{1 \%}$ & $\mathbf{3 7 . 3 2}$ & $\mathbf{8 8 . 5 9}$ & $\mathbf{5 7 . 6 5}$ \\
\cline { 2 - 5 } & $\mathbf{2 \%}$ & 65.23 & 75.33 & 67.37 \\
\cline { 2 - 5 } & $\mathbf{3 \%}$ & 43.21 & 82.14 & 79.49 \\
\cline { 2 - 5 } & Means & $\mathbf{6 1 . 5 1}$ & 116.07 & 90.50 \\
\hline Control & 42.73 & 57.13 & 53.35 \\
\hline L.S.D 0.05 Compounds & $\mathbf{5 . 3 5 1} * * *$ & $\mathbf{5 . 3 5 1} * * *$ & $\mathbf{5 . 3 5 1} * * *$ \\
\hline L.S.D 0.05 Concentrations & $\mathbf{4 . 6 3 4} * *$ & $\mathbf{4 . 6 3 4} * * *$ & $\mathbf{4 . 6 3 4} * *$ \\
\hline
\end{tabular}

compared with $53.35 \mathrm{mg}$ glucose $/ \mathrm{ml}$ for control. The concentration $2 \%$ from Basfoliar gave the highest trehalase enzyme $(85.65 \mathrm{mg}$ glucose $/ \mathrm{ml})$.

Data presented in Table (4), showed that the means of trehalase enzyme were $83.53,57.64$ and $79.12 \mathrm{mg}$ glucose $/ \mathrm{ml}$ for Basfoliar, Tecamin and stimoful respectively when the $4^{\text {th }}$ and $5^{\text {th }}$ instar larvae fed on the treated leaves. Highly significant differences were found between the three treatments and control. The concentration 2\% from Basfoliar gave the highest trehalase enzyme in haemolymph compared with the other concentrations.

At the same line, Lakshmikumari et al. (1997) postulated that, the high activities of the amylase and protease in haemolymph and midgut tissue might be due to a greater utilization of exogenous proteins resulting in the production of more silk. Similar trend was also reported by Arundhuti and Bassappa (2005) found that supplementation of potassium chloride to the $5^{\text {th }}$ instar larval of the silkworm $B$. mori make increase on haemolymph trehalose with high concentration in comparison with control.

All the above results may be also explained by the earlier researches indicated that, mulberry responds to nitrogen $(\mathrm{N})$ since it is a constituent of 
plant proteins and vitamins. Potassium (K) plays an important role in plant biochemical functions, development, and yield of foliage and leaf quality improvement. It was also found to have a stimulating effect on growth of silkworm and silk production (Horie and Watanabe, 1986; Shankar and Rangaswamy, 1999).

Conclusively, mulberry leaves fortified with foliar fertilizers with increased concentrations (2\% and 3\%) increased total protein, carbohydrates and protein enzymes activities and activated protein production in mulberry silkworm B. mori.

\section{REFERENCES}

Arundhuti, B. and Bassappa, B. K. (2005): The biochemical effects of potassium chloride on the silkworm, Bombyx mori L. Insect Science, 12 (2): 95-100.

Ashfag, M.; Wahla, M. A.; Parvez, I. and Islam, M. (2006): Influence of different nutritional sources on various developmental and biological aspects of silkworm, B. mori L. World Journal of Agricultural Science, 2 (3): 233-238.

Bhattacharya, A. and Kaliwal, B. B. (2005): Synergetic effects of potassium and magnesium chloride biochemical contents of the silkworm, Bombyx mori L. Capian Journal of Environmental Science, 3 (1): 15-21.

Das, P.; Bhattacharya, P. R.; Unni, B. G. and Deka, P. C. (2004): Consumption and utilization of food (Persea bombycina) in relation to larval development and silk protein biosynthesis by semidomesticated muga silkworm, Antheraea assama. Indian Journal Seric., 43 (1):57-65.

El-Sheakh, A. A.; Zannoon, A. A. and El-Sayed, M. F. (1994): Biochemical effect of stored mulberry leaves on some enzymes activities in the haemolymph of Bombyx mori L. Egyptian Journal of Agriculture Research, 72 (3): 721-727.

Franco O. L; Rigden, D. J; Melo, F. R and Grossi-de-Sá, M. F. (2000): Plant $\alpha$-amylase inhibitors and their interaction with insect $\alpha$ amylase: structure, function and potential for crop protection. Eur. Journal of Biochem., 267: 397-412.

Franco, O. L; Rigden, D. J; Melo, F. R and Grossi-de-Sa M. F. (2002): Activity of wheat $\alpha$-amylase inhibitors towards bruchid $\alpha$-amylases and structural explanation of observed specification. Eur. Journal of Biochem., 269: 2166-2173. 
Gornall, A. G.; Bardawil, C. D. and David, M. M. (1949): Determination of serum protein by means of bruit reaction. Journal of Biological Chem., 177: 751-766.

Horie, Y. and Watanaba, K. (1986): Daily utilization of nitrogen in food by the silkworm, Bombyx mori (Lepidoptera: Bombycidae). Applied Entomology and Zoology, 21 (2): 289-298.

Ishaaya, I. and Swiriski, E. (1976): Trehalase, invertase and amylase activities in the black scale, Saissetic oleae and their relation to host adaptility. Journal of Insect Physiology, 16: 1025-1029.

Ito, T. (1978): Silkworm Nutrition, In "The silkworm: An important laboratory tool. (ed.: Tazima, Y.) Kodansha Ltd., Japan. 121-157.

Krishnaswami, S. (1978): New technology of silkworm rearing. Central Sericulture Researches and Training, Inst., Mysore Bull., 2:1- 10.

Lakshmikumari, B.; Ananthanarayana, S. R. and Jayaprakash, K. (1997): Effect of radiation on the activity of digestive enzymes in the silkworm Bombyx mori. Sericologia, 37(2):221-228.

Li, X. Y. and Zhu, O. X. (1985): Mechanisms of silk increase in silkworm by N15 urea administration. Science of Sericulture, 9 (4): 209-213.

Machii, H. (1989): Varietal differences of nitrogen and amino acid contents in mulberry leaves for rearing silkworms. JARQ., 25 :202-208.

Mahesha, H. M.; Rajashekhargouda, R. and Rayar, S. G. (1999): Effect of aqueous extracts of few botanicals with special reference to weeds on Bombyx mori L. The Proceeding of the XVIIIth International Sericultural Commission Congress, Cairo- Egypt, 1216 October, 114-118.

Mahmoud, S. M. (1988): Activation of silk secretion by silkworm, Philosamia ricini and Bombyx. mori after applying antibiotics. Ph. D. Thesis, Faculty Agric., Cairo University, Egypt.

Mesbah, H. A.; El-Sayed, Nagda, A. A.; Yehia, Wagiha, H.; Mahmoud, Mona, M. and El-Karaksy, I. A. (2000): Effect of some natural Plant Products on the Productivity of the mulberry silkworm, Bombyx mori L. Adv. Agric. Res., 5 (2), 1331-1344.

Mullins, D. E. (1985): Chemistry and physiology of the haemolymph. Comprehensive Insect Physiology, Pergamon Press. Oxoford, 3 : 355-450.

Murugan, K.; Jeyabalan, D.; Kumar, N. S.; Nathan, S. S.; Sivaprakasam, N.; Pandey, A.; Soccol, C. R. and Josh, V. K. (1998): Growth promoting effects of plant products on silkwormbiotechnological approach. Journal of Scientific and Industrial Research, 57:10-11,740-745; 22 ref. 
Nagata, M. and Kobayashi, J. (1990): Effect of nutrition on storage protein concentrations in the larval haemolymph of the silkworm Bombyx mori. Journal Seric. Science Jpn., 59:469-474.

Naveed, A.; Dayananda G.Y. and Hosetti B. B. (2009): Effect of some selected insecticides on the activity of invertase at different stages of pentatomid bug Cyclopelta siccifolia W. Our Nature, 7: 222-225.

Parra, J. R. P. (1991): Consumoe utilizaçào de alimentos por insetos. In: PANIZZI, A.R., Parra, J.R.P. Ecologia nutricional de Insetose suas Implicaçòes no manejo de pragas. 359 P. Manole, Sào Paulo.

Reitman, S. M. D. and Frankcl, S. (1957): A colorimetric method for the determination of serum glutamic-oxaloacetic and glutamic-pyruvic transaminase. Annual Journal Clin. Pathol., 28: 56-62.

Sarker, A. A.; Haque, M. R.; Rab, M. A. and Absar, N. (1995): Effects of feeding mulberry (Morus sp.) leaves supplemented with different nutrients to silkworm (Bombyx mori L.). Current Science, 69 (2): 185-188.

Shankar, M A. and Rangaswamy, B. T. (1999): Effect of applied nitrogen and potassium on mulberry leaf yield and quality in relation to silkworm cocoon characters. Better Crops International, 13 (2): 20-21.

Singaravelu, G.; Anbu, S.; Prabu, P. and Govindaraju, K. (2004): Effect of supplementation of micronutrient, magnesium sulphate on certain aspects of silkworm, Bombyx mori L. Journal Ent. Research, 28 (3): 205-210.

Singh, S. P.; Singh, M. K. and Singh, G. B. (1985): Changes in the transaminase activity in the middle and posterior silk gland tissues of eri-silkworm Philosamia ricini in relation to spinning process. Acta Physiology Hung., 66 (1): 61-64.

Singhal, B. K. and Rajan, M. V. (1998): An insight into silkworms' food. Indian Textile Journal, 108 (10): 86-88.

Snedecor, G. W. and Cochran, W. G. (1982): Statistical Methods. Iowa State University Press, Amer. Iowa, USA.

Wagiha, H. Y. and Mona, M. M. (2008): Effect of certain fertilizers on the productivity of mulberry silkworm, B. mori L. Egyptian Journal Agriculture Research, 86 (2): 831-838. 
دراسة تأثير أوراق التوت المدعمة ببعض الأسمدة الورقية على بعض الصفات

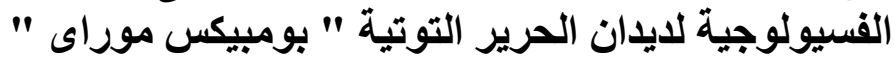

عبد الحميا على إبراهيم زنون - إيمان محمود حسان - غادة عبد المنعم مرسى معهد بحوث وقاية النباتات ـ مركز البحوث الزر اعية ـ الدقى ـ مصر.

أجريت هذه الدراسة لتقييم تأثير بعض الأسمدة الورقية (Basfoliar combi ctip) (Stimoful Tecamin max,

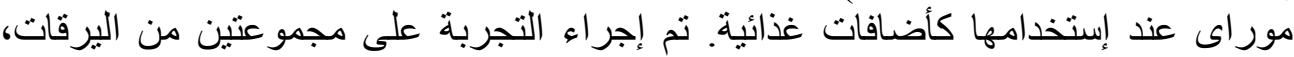

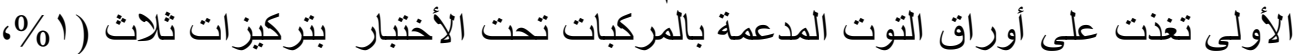

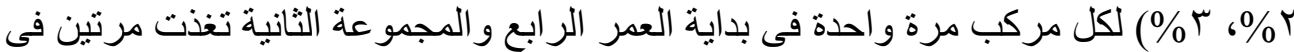

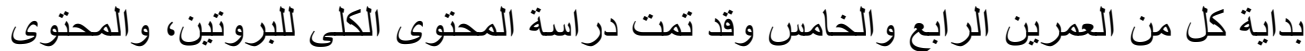

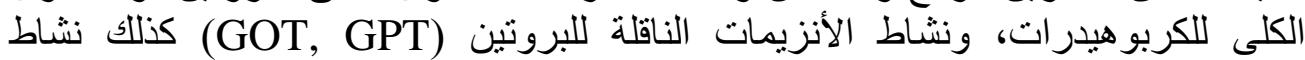
إنزيمات الكربو هيدر ات (amylase, invertase and trehalase) فى دم اليرقات. وقد لوحظ تفوق النتائج الخاصة باليرقات التى تغذت مرتين في بداية العمرين الر ابع و الخامس

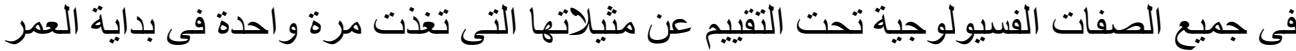

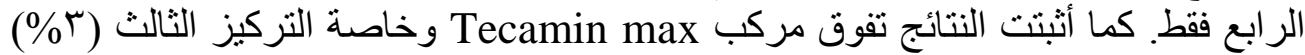

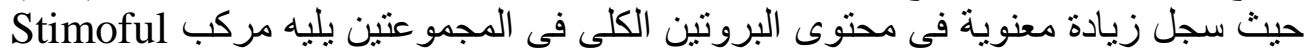

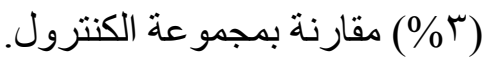

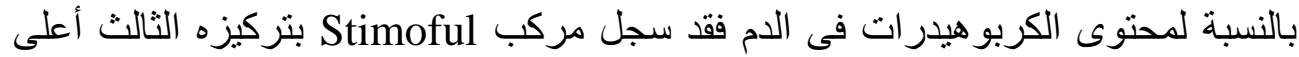

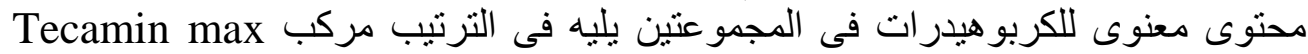
ومركب Basfoliar combi ctip.

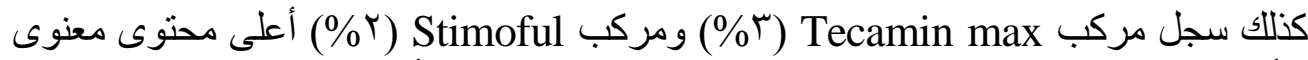
للأنزيمات الناقلة للبروتين خاصة GOT فى المجمو عتين وكذلك أنزيم أن أنزيم GPT لم يسجل أى نتائج معنوية للمجمو عة التى تغذت فئ فئ بداية العمر الرابع. وقد لوحظ أن مركب Basfoliar combi ctip بتركيزه الثالث ومركب Stimoful (r) قد سجل زيادة معنوية في نشاط الأنزيمين amylase and trehalase في دم اليرقات في في المجمو عتين مقارنة بالكنترول. التوصية: نستخلص من النتائج السابقة لهذه الدراسة ضرورة تدعيم وتعزيز ورق التوات التوت

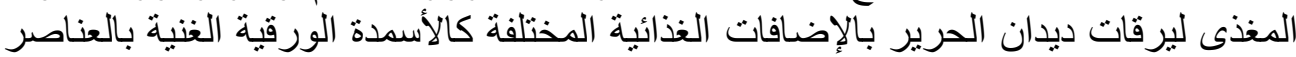

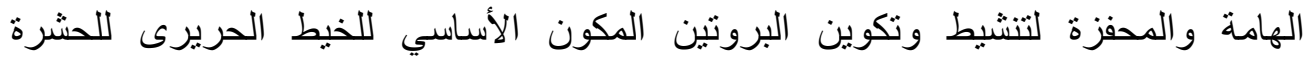

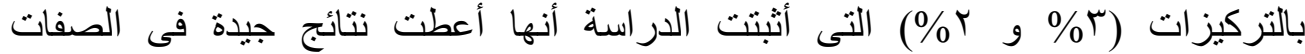

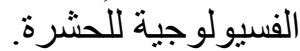

